\title{
FAKTOR-FAKTOR YANG BERHUBUNGAN DENGAN STRES KERJA PADA DOSEN TETAP DI STIKES Y BENGKULU
}

\author{
Rina Aprianti 1), Agus Surono ${ }^{2)}$ \\ Program Studi Kesehatan Masyarakat \\ STIKES Tri Mandiri Sakti Bengkulu, Bengkulu, Indonesia \\ Email: rina.aprianti89@gmail.com
}

\begin{abstract}
Abstrak
Stres kerja adalah suatu keadaan yang dialami seseorang akibat dari kombinasi sumber stres di tempat kerja, karakteristik individu, dan stres di luar dari organisasi. Penelitian ini bertujuan untuk mengetahui faktor-faktor yang berhubungan dengan stress kerja pada dosen tetap di STIKES Y Bengkulu. Jenis penelitian ini adalah penelitian survei analitik dengan pendekatan cross sectional. Sampel dalam penelitian ini adalah dosen tetap di STIKES Y Bengkulu yang berjumlah 36 orang. Variabel bebasnya adalah umur, status pernikahan dan jumlah anak, variabel terikatnya adalah stres kerja. Analisis yang digunakan adalah chi square dan fisher exact, yaitu untuk menguji ada tidaknya hubungan antara variabel bebas dan terikat. Hasil penelitian ini terdapat: hubungan yang signifikan secara statistik antara umur $(\mathrm{p}=0,001)$ dengan stres kerja. Tidak ada hubungan yang signifikan secara statistik antara status pernikahan $(\mathrm{p}=0,069)$, jumlah anak $(\mathrm{p}=0,073)$ dengan stres kerja
\end{abstract}

Kata kunci : Umur, Status Pernikahan, Jumlah Anak, Stres Kerja

\section{ABSTRACT}

Job stress is a condition experienced by a person due to a combination of sources of stress at work, individual characteristics, and stress outside of the organization. This study aims to determine the factors associated with work stress on permanent lecturers at STIKES Y Bengkulu. This type of research is analytic survey research with cross sectional approach. The sample in this study were 36 permanent lecturers at Bengkulu Y STIKES. The independent variables are age, marital status and number of children, the dependent variable is job stress. The analysis used is chi square and fisher exact, which is to examine whether there is a relationship between independent and dependent variables. The results of this study are: statistically significant relationship between age $(p=0.001)$ with work stress. There was no statistically significant relationship between marital status $(p=0.069)$, number of children $(p=$ 0.073) with work stress

Keywords: Age, Marital Status, Number of Children, Job Stress 


\section{PENDAHULUAN}

WHO (Word Health Organization) menyatakan bahwa stres merupakan penyakit epidemi yang menyebar bukan hanya di Amerika tetapi di seluruh dunia. Bahkan dalam laporan PBB (Perserikatan BangsaBangsa), penyakit stres kerja ini mendapat julukan "penyakit abad 20". Penelitian Northwestern National Life Insurance tahun 1993 menyimpulkan bahwa 1 juta kasus absensi pekerja berkaitan dengan masalah stres, 1/3 pekerja yang mengalami stres berniat untuk langsung mengundurkan diri, sekitar $70 \%$ menyatakan bahwa stres akibat kerja telah merusak kehidupan fisik dan mental pekerja. Selain itu, sekitar 27\% aspek pekerjaan dapat menimbulkan stres kerja bagi pekerja paling tinggi, sedangkan sekitar $46 \%$ sangat atau luar biasa tinggi (Losyk, 2007).

Selanjutnya menurut Winefield et al. (dalam Shen et al., 2014), tenaga pengajar merupakan suatu profesi yang sangat berkaitan dengan stres yang tinggi, terbukti pada penelitian yang dilakukan pada 17 universitas di Australia ditemukan bahwa $43 \%$ dari staf akademi dan $37 \%$ dari staf non akademi mengalami stres kerja. Arismunandar (dalam Safaria, 2011) menemukan bahwa 30,27\% yaitu sekitar 24.000 dari 80.000 guru mengalami stres kerja berat.

Menurut Tarwaka et al. (2004), stres kerja yang dialami seseorang dapat disebabkan karena beberapa faktor, antara lain: kondisi individu (umur, jenis kelamin, temperament, genetika, intelegensia, pendidikan, dan kebudayaan), ciri kepribadian (introver atau ekstrover, tipe A dan tipe B, tingkat emosi, kepasrahan, kepercayaan diri), sosial kognitif (dukungan sosial, hubungan sosial dengan lingkungan sekitarnya), dan strategi untuk menghadapi setiap stres yang muncul.

STIKES Y Bengkulu merupakan sekolah tinggi ilmu kesehatan strata S1 dengan program studi kesehatan masyarakat, program studi keperawatan, dan program studi kebidanan. Dosen di STIKES Y Bengkulu memiliki tugas dan fungsinya masing-masing, tetapi selama menjalankan tugasnya masih ada yang mengalami kesulitan untuk membagi waktu antara keluarga dan pekerjaannya sehingga konsentrasinya terganggu.

Berdasarkan latar belakang tersebut maka rumusan masalah dalam penelitian ini adalah "Adakah hubungan antara faktor usia, status pernikahan, dan jumlah anak dengan stress kerja pada dosen tetap di STIKES Y Bengkulu?". Tujuan penelitian ini adalah untuk mengetahui hubungan antara faktor usia, status pernikahan, dan jumlah anak dengan stress kerja pada dosen tetap di STIKES Y Bengkulu.

\section{METODE PENELITIAN}

Jenis penelitian ini adalah penelitian survei analitik dengan pendekatan cross sectional, untuk mengetahui hubungan antara umur, status pernikahan dan jumlah anak dengan stres kerja. Populasi pada penelitian ini adalah semua dosen tetap di STIKES Y Bengkulu dengan jumlah 42 orang. Teknik pengambilan sampel pada penelitian ini dengan cara total sampling dengan kriteria inklusi meliputi semua dosen tetap STIKES Y baik laki-laki maupun perempuan, bersedia menjadi responden dalam penelitian dan kriteria eksklusi meliputi dosen tetap 
yang sedang dalam masa cuti dan sedang dalam tugas belajar. Setelah dilakukan proses inklusi dan ekslusi maka jumlah sampel pada penelitian ini adalah 36 dosen tetap. Instrument penelitian yang digunakan untuk mengumpulkan data pada penelitian ini dengan menggunakan kuesioner dengan alat pengukuran yang berbeda untuk setiap variabel. Analisis data pada penelitian ini terdiri dari analisis univariabel, analisis bivariabel menggunakan uji Chi square dan Fisher Exact.

\section{Analisis Univariat}

\section{HASIL}

Tabel 1. Distribusi Frekuensi Umur

\begin{tabular}{lrc}
\hline \multicolumn{1}{c}{ Karakteristik } & \multicolumn{2}{c}{ Jumlah $(\mathrm{n}=36)$} \\
\cline { 2 - 3 } & $\mathrm{N}$ & $(\%)$ \\
\hline Umur & 16 & 44.44 \\
$<30$ tahun & 20 & 55.56 \\
$\geq 30$ tahun & 36 & 100 \\
\hline Jumlah & & dengan frekuensi sebanyak 20 orang dengan \\
\hline Hasil analisis didapatkan mayoritas & & persentase sebanyak 55,56\%.
\end{tabular}

Tabel 2. Distribusi Frekuensi Status Pernikahan

\begin{tabular}{|c|c|c|}
\hline \multirow[t]{2}{*}{ Karakteristik } & \multicolumn{2}{|c|}{ Jumlah $(n=36)$} \\
\hline & $\mathrm{N}$ & $(\%)$ \\
\hline Status Pernikahan & & \\
\hline Belum menikah & 6 & 16.67 \\
\hline Menikah & 30 & 83.33 \\
\hline Jumlah & 36 & 100 \\
\hline
\end{tabular}

Tabel 3. Distribusi Frekuensi Jumlah Anak

\begin{tabular}{|c|c|c|}
\hline \multirow[t]{2}{*}{ Karakteristik } & \multicolumn{2}{|c|}{ Jumlah $(n=36)$} \\
\hline & $\mathrm{N}$ & $(\%)$ \\
\hline Jumlah Anak & & \\
\hline Tidak punya anak & 10 & 27.78 \\
\hline Punya anak $\leq 2$ & 21 & 58.33 \\
\hline Punya anak > 2 & 5 & 13.89 \\
\hline Jumlah & 36 & 100 \\
\hline
\end{tabular}

Tabel 4. Distribusi Frekuensi Stres Kerja 


\begin{tabular}{lcc}
\hline Karakteristik & \multicolumn{2}{c}{ Jumlah $(\mathrm{n}=36)$} \\
\cline { 2 - 3 } & $\mathrm{N}$ & $(\%)$ \\
\hline Stres Kerja & 20 & 55.56 \\
Rendah & 16 & 44.44 \\
Sedang & 36 & 100 \\
\hline Jumlah & & dengan frekuensi sebanyak 20 orang dengan \\
\hline Hasil analisis didapatkan mayoritas & & persentase sebanyak 55,56\%.
\end{tabular}

\section{Analisis Bivariat}

Tabel 5. Hubungan antara Umur dengan Stres Kerja

\begin{tabular}{lcccccccc}
\hline & \multicolumn{4}{c}{ Stres Kerja } & \multirow{2}{*}{ Jumlah } & \multirow{2}{*}{$p$} \\
\cline { 3 - 6 } & & \multicolumn{2}{c}{ Rendah } & \multicolumn{2}{c}{ Sedang } & & \\
\cline { 2 - 7 } & $\mathrm{N}$ & $\%$ & $\mathrm{~N}$ & $\%$ & $\mathrm{n}$ & $\%$ & \\
\hline \multirow{2}{*}{ Umur } & $<30$ tahun & 4 & 25.00 & 12 & 75.00 & 16 & 44.44 & \multirow{2}{*}{0.001} \\
& $\geq 30$ tahun & 16 & 80.00 & 4 & 20.00 & 20 & 55.56 & \\
\hline \multirow{2}{*}{ Jumlah } & 20 & 55.56 & 16 & 44.44 & 36 & 100 & \\
\hline
\end{tabular}

Hasil analisis hubungan antara umur dengan stres kerja pada dosen tetap menunjukkan bahwa dosen tetap dengan umur < 30 tahun mengalami stres kerja rendah sebanyak 4 orang $(25 \%)$ dan stres kerja sedang sebanyak 12 orang (75\%). Dosen tetap dengan umur $\geq 30$ tahun mengalami stres kerja rendah sebanyak 16 orang $(80 \%)$ dan stres kerja sedang sebanyak 4 orang (20\%). Hasil uji bivariabel antara umur dengan stres kerja memperoleh nilai $p=0,001(p<0,05)$, yang berarti terdapat hubungan yang signifikan secara statistik antara umur dengan stres kerja pada dosen tetap di STIKES Y.

Tabel 6. Hubungan antara Status Pernikahan dengan Stres Kerja

\begin{tabular}{|c|c|c|c|c|c|c|c|c|}
\hline & & \multicolumn{4}{|c|}{ Stres Kerja } & \multirow{2}{*}{\multicolumn{2}{|c|}{ Jumlah }} & \multirow[t]{3}{*}{$p$} \\
\hline & & \multicolumn{2}{|c|}{ Rendah } & \multicolumn{2}{|c|}{ Sedang } & & & \\
\hline & & $\mathrm{N}$ & $\%$ & $\mathrm{n}$ & $\%$ & $\mathrm{n}$ & $\%$ & \\
\hline Status & Belum & 1 & 16.67 & 5 & 83.33 & 6 & 16.67 & 0.069 \\
\hline \multirow[t]{2}{*}{ Pernikahan } & Menikah & & & & & & & \\
\hline & Menikah & 19 & 63.33 & 11 & 36.67 & 30 & 83.33 & \\
\hline Jumlah & & 20 & 55.56 & 16 & 44.44 & 36 & 100 & \\
\hline
\end{tabular}

Hasil analisis hubungan antara status pernikahan dengan stres kerja pada dosen tetap menunjukkan bahwa dosen tetap belum menikah mengalami stres kerja rendah sebanyak 1 orang $(16,67 \%)$ dan stres kerja sedang sebanyak 5 orang $(83,33 \%)$. Dosen tetap yang menikah mengalami stres kerja rendah sebanyak 19 orang $(63,33 \%)$ dan stres kerja sedang sebanyak 11 orang $(36,67 \%)$. Hasil uji bivariabel antara status 
pernikahan dengan stres kerja memperoleh nilai $p=0,069(p>0,05)$, tidak ada hubungan yang signifikan secara statistik antara status pernikahan dengan stres kerja pada dosen tetap di STIKES Y.

Tabel 7. Hubungan antara Jumlah Anak dengan Stres Kerja

\begin{tabular}{|c|c|c|c|c|c|c|c|c|}
\hline & \multicolumn{4}{|c|}{ Stres Kerja } & \multirow{2}{*}{\multicolumn{2}{|c|}{ Jumlah }} & \multirow[t]{3}{*}{$p$} \\
\hline & & \multicolumn{2}{|c|}{ Rendah } & \multicolumn{2}{|c|}{ Sedang } & & & \\
\hline & & $\mathrm{N}$ & $\%$ & $\mathrm{n}$ & $\%$ & $\mathrm{n}$ & $\%$ & \\
\hline \multirow[t]{2}{*}{$\begin{array}{l}\text { Jumlah } \\
\text { Anak }\end{array}$} & $\begin{array}{l}\text { Tidak } \\
\text { mempunyai } \\
\text { anak }\end{array}$ & 3 & 30.00 & 7 & 70.00 & 10 & 27.78 & 0.073 \\
\hline & $\begin{array}{l}\text { Mempunyai } \\
\text { anak } \leq 2 \text { dan } \\
>2\end{array}$ & 17 & 80.95 & 9 & 42.85 & 26 & 72.22 & \\
\hline Jumlah & & 20 & 55.56 & 16 & 44.44 & 36 & 100 & \\
\hline
\end{tabular}

Hasil analisis hubungan antara jumlah anak dengan stres kerja pada dosen tetap menunjukkan bahwa dosen tetap yang tidak mempunyai anak mengalami stres kerja rendah sebanyak 3 orang (30\%) dan stres kerja sedang sebanyak 7 orang $(70 \%)$. Dosen tetap yang mempunyai anak $\leq 2$ mengalami stres kerja rendah sebanyak 13 orang $(61,90 \%)$ dan stres kerja sedang sebanyak 8 orang $(38,10 \%)$, dosen tetap yang mempunyai anak $>2$ mengalami stres kerja rendah sebanyak 4 orang (800\%) dan stres kerja sedang sebanyak 1 orang (20\%). Hasil uji bivariabel antara jumlah anak dengan stres kerja memperoleh nilai $p=$ 0,073 ( $p>0,05$ ), yang berarti tidak ada hubungan yang signifikan secara statistik antara jumlah anak dengan stres kerja pada dosen tetap di STIKES Y.

\section{PEMBaHASAN}

Analisis bivariabel antara umur dengan stres kerja pada dosen tetap di STIKES Y Bengkulu menunjukkan terdapat hubungan yang signifikan secara statistik antara umur dengan stres kerja pada dosen tetap di STIKES Y. Hal ini sejalan dengan penelitian yang dilakukan oleh Fitri (2013), yang menyatakan bahwa ada hubungan umur dengan stres kerja.

Umur merupakan salah satu faktor yang dapat menyebabkan seorang pekerja mengalami stres akibat kerja, yaitu semakin tua umur pekerja dapat menyebabkan rendahnya kemungkinan untuk mengalami stres kerja karena pekerja dengan umur yang sudah tua akan memiliki kematangan kondisi kesehatan mentalnya. Akbar dan Akhter (2011) yang menyatakan bahwa pekerja yang umurnya lebih muda dapat mengalami stres dibandingkan dengan yang umurnya lebih tua.

Hasil penelitian ini menunjukkan bahwa dosen tetap dengan umur $<30$ tahun sebagian besar mengalami stres kerja sedang tetapi ada 4 orang yang mengalami stres kerja rendah karena karena sudah mampu mengembangkan beberapa ketahanan terhadap tekanan pekerjaan yang dilakukan sebagai dosen. Sedangkan dosen tetap yang 
berumur $\geq 30$ tahun sebagian besar mengalami stres kerja yang rendah tetapi ada 4 orang yang mengalami stres kerja sedang karena banyaknya pekerjaan yang harus diselesaikan ditambah lagi mayoritas dosen tetap adalah perempuan yang suasana hatinya lebih sensitif dibandingkan laki-laki. Hal ini terlihat dari distribusi dan frekuensi stres kerja yang dialami dosen tetap yang sekitar 24 orang $(66,67 \%)$ mengalami suasana hati yang mudah berubah kadang sedih kadang gembira.

Analisis bivariabel antara status pernikahan dengan stres kerja pada dosen tetap di STIKES Y Bengkulu menunjukkan tidak ada hubungan yang signifikan secara statistik antara status pernikahan dengan stres kerja pada dosen tetap di STIKES Y. Hal ini sejalan dengan penelitian yang dilakukan oleh Nurhidayati (2016), yang menyatakan bahwa tidak ada hubungan yang signifikan antara status pernikahan dengan stres kerja pada karyawan di Unit Instalasi Binatu.

Selanjutnya, Raj (2015) dari hasil penelitiannya menjelaskan bahwa status pernikahan tidak berhubungan dengan stres kerja. Penelitian tersebut dilakukan pada staf perawat yang bekerja di unit perawatan kritis di rumah sakit Trivandrum Kerala. Begitu juga dengan penelitian yang dilakukan oleh Noviati (2016), yang menemukan bahwa tidak ada hubungan antara status pernikahan dengan stres kerja.

Status pernikahan merupakan salah satu faktor individu yang dapat menyebabkan terjadinya stres kerja, tetapi pada penelitian ini stres kerja tidak dipengaruhi oleh status pernikahan karena mereka bisa menyesuaikan dirinya, baik di lingkungan keluarga maupun di lingkungan kerja, sehingga urusan keluarga tidak terbawa ke tempat kerja. Selain itu, keputusan mereka untuk bekerja sudah mendapatkan dukungan dari keluarga. Hal ini sejalan dengan pendapat Nurhidayati (2016), bahwa dukungan yang dilakukan oleh keluarga dapat memberikan semangat kepada karyawan, sehingga tidak ada beban pikiran yang dibawa ke tempat kerja.

Hasil penelitian ini menunjukkan bahwa dosen dengan status belum menikah terdapat 5 orang yang mengalami stres kerja sedang karena dapat dipengaruhi oleh hal lain di luar pekerjaan, seperti mengenai masalah pasangan hidup yang akan mendampingi mereka dan dapat mendukung pekerjaan mereka. Sedangkan dosen dengan status menikah justru paling banyak mengalami stres kerja rendah, mereka yang sudah menikah sudah memiliki kematangan emosional karena faktor usia dapat mempengaruhi ketahanan terhapat tekanan pekerjaan.

Analisis bivariabel antara jumlah anak dengan stres kerja pada dosen tetap di STIKES Y Bengkulu menunjukkan tidak ada hubungan yang signifikan secara statistik antara jumlah anak dengan stres kerja pada dosen tetap di STIKES Y. Hal ini sejalan dengan penelitian yang dilakukan oleh Eguchi et al. (2016) yang menyatakan bahwa faktor psikososial dan memiliki anak tidak memberikan efek di tempat kerja.

Hal ini karena dosen tetap yang sudah mempunyai anak maupun yang belum mempunyai sudah mendapat dukungan keluarga untuk bekerja sehingga tidak menjadi beban yang dapat memicu terjadinya stres akibat kerja. Selain itu juga, 
kebijakan yang diberikan kepada dosen tetap untuk izin jika ada anggota keluarga yang sakit atau hal penting lainnya terkait dengan anak tidak sulit serta di dalam lingkungan STIKES Y itu sendiri sudah tersedia tempat penitipan anak sehingga dosen tetap yang masih memiliki anak balita bisa menitipkan anaknya di sana tanpa ada kekhawatiran yang berlebihan karena di sela waktu istirahat bisa melihat anaknya.

\section{KESIMPULAN}

1. Ada hubungan yang signifikan secara statistik antara umur dengan stres kerja pada dosen tetap di STIKES Y Bengkulu.

2. Tidak ada hubungan yang signifikan secara statistik antara status pernikahan dengan stres kerja pada dosen tetap di STIKES Y Bengkulu.

3. Tidak ada hubungan yang signifikan secara statistik antara jumlah anak dengan stres kerja pada dosen tetap di STIKES Y Bengkulu.

\section{DAFTAR PUSTAKA}

Fitri, A.M. (2013) Analisis Faktor-Faktor yang Berhubungan dengan Kejadian Stres Kerja pada Karyawan Bank (Studi pada Karyawan Bank BMT). J Kesmas, 2.

Akbar, A., \& Akhter, W., (2011). Faculty Stress at Higher Education: A Study on the Business Schools of Pakistan. Wold Academic of Science, 49, pp. 1079-1083.

Nurhidayati, W.O. (2016) Hubungan Suhu Ruangan dan Karakteristik Individu dengan Stres Kerja Pada Karyawan Di Unit Instalasi Binatu RSUP Dr. Sardjito Yogyakarta. Tesis. Program
Pascasarjana IKM Universitas Gadjah Mada.

Raj, K.A., (2015). Job Stress among Staff Nurses Working in Critical Care Units and Their Socio-Demographic Correlates: A Cross Sectional Survey. J Global for Research Analysis, Vol.4. pp.334-335.

Noviati. (2016) Hubungan antara Kelelahan, Shift, dan Beban Kerja dengan Stres Kerja Karyawan di PT Pulogadung Tempajaya. Tesis. Program Pascasarjana IKM Universitas Gadjah Mada.

Eguchi, H., Shimazu, A., Fujiwara, T., Itawa, N., Shimada, K., Takahashi, M., Tokita, M., Watai, I., Kawkami, N. (2016) The Effect of Workplace Psychosocial Factors on Whether Japanese Dual-Earner Couple with Preschool Children Have Additional Children: a Prospective Study. Industrial Health, 54, pp.498-504.

Losyk, B. (2007) Kendalikan Stres Kerja Anda! Cara Mengatasi Stres dan Sukses di Tempat Kerja. Jakarta: PT. Gramedia Pustaka Utama.

Safaria, T. (2011) Peran Religious Coping Sebagai Moderator dari Job Insecurity terhadap Stres Kerja pada Staf Akademik. Humanitas, VIII, pp.155170.

Shen, X., Yang Y.L., Wang, Y., Liu, L., Wang, S., \& Wang, L. (2014) The Association between Occupational Stress and Depressive Symptoms and The Mediating Role of Psychological Capital among Chinese University Teachers: A Cross-Sectional Study. BMC Psychiatry, 14, pp.1-8. 
Tarwaka \& Sudiajeng, L. (2004) Ergonomi untuk Keselamatan Kesehatan Kerja dan Produktivitas, Surakarta: Uniba Press Surakarta. 